\author{
M.Zh. Balpanova ${ }^{1}$, G.A. Yessenbayeva ${ }^{1}$, D.K. Takhanov ${ }^{2}$ \\ ${ }^{1}$ Ye.A. Buketov Karaganda State University, Kazakhstan; \\ ${ }^{2}$ Karaganda State Technical University, Kazakhstan \\ (E-mail: balpanova86@mail.ru)
}

\title{
The calculation of the side pressure coefficient in conditions of the limited stress situation
}

\begin{abstract}
In this article the method of the side pressure coefficient determining in the conditions of limited stress situation is considered. Envelopes of limited stresses circles on the strength passport and the rectilinear envelope in the region of limited extending stresses for different geological conditions are compared. The calculation-graphical method for the side pressure coefficient determining in areas of compressive and extending stresses is given and the comparative analysis of its results is done. It is obtained that the coefficients of the side pressure for the rectilinear and curvilinear envelopes in the zone of extending stresses are equal to each other.
\end{abstract}

Keywords: strength passport, Poisson's coefficient, lateral pressure, rock formation, Mohr's circles, side expansion, mine working.

With an increase in the depth of the underground mine working the load on it increases from the weight of the overlying strata of rocks. In deep mines this load reaches a considerable value. At a great depth of underground mining the value of the side pressure becomes significant and must be taken into account. The adhesion and friction between the particles in the rocks of the mine working walls is not sufficient for them to stand without collapsing and could serve as firm supports of the arch.

The value of the side pressure will be greater, if the rock will be weaker and mine working will have a height which will be greater. This value can be defined as the pressure on the retaining wall of the sliding prisms loaded from above.

For the case of a uniform loading of prisms the side pressure will be calculated is calculated by the formula [1]:

$$
R_{0}=\frac{\gamma}{2}\left(2 h_{0}+H\right) H \operatorname{tg}^{2} \frac{90^{0}-\varphi}{2},
$$

where is a height of mine working height, $m ; h_{0}$ is a reduced height of loading of prisms from above, $m ; \gamma$ is a volume weight of rocks, $\frac{t}{m^{3}} ; \varphi$ is an angle of internal resistance (friction) of rocks, deg.

In mine workings of a small height $3.5 \div 5 \mathrm{~m}$, values of the pressure $R_{0}$ is small too, but in large chambers, tunnels and mine workings, which have the considerable height, with weak and medium rocks one has to take into account the magnitude of the side pressure and introduce it into calculations.

Lateral rocks serve as the arch supports of natural balance and perceive the resultant expanse of the arch and the load on the arch. The magnitude of this resultant depends mainly on a width of mine workings and a strength of rocks. The value of this resultant will be greater,if the side rocks will be loaded greater too.

Researchers (Birmaumer, Ritter, M.M. Protodyakonov, etc.), dealing with the side pressure questions [2], determine its magnitude from the conditions of sliding of the side prisms.

Ritter connects the definition of side pressure with the forces of adhesion and friction along the slipping plane of the lateral prism. According to Ritter, a span of a arch collapse in the mine working ceiling remains equal to the width of a mine working with the sliding of the side prisms. It is difficult to assume, since the lateral rocks near the upper mine workings angles seem to be the most stressed [2].

Professor M.M. Protodyakonov believes that a pressure from the ceiling of a mine working is determined by a weight of a rock in the volume of the arch collapse, having a span which is equal to a width of a mine working [3]. It is supposed, there are also loose, weak rocks in the walls of a mine workings and the semiprolet of the arch is increased by the value where is the angle of sliding of the side prisms, $\theta=\frac{90^{0+\varphi}}{2}$. Professor M.M. Protodyakonov gives the following formulas for determining value a side pressure 


$$
t=\gamma t g^{2} \frac{90^{0}-\varphi}{2}\left[z\left(1+\frac{2 t g\left(90^{0}-\varphi\right)}{3 f}\right)+\frac{4 a}{3 f}\right],
$$

where $\varphi$ is an angle of a internal friction of lateral rocks, deg.; $f$ is a fortress coefficient of a roof rock.

In reality [2], under a parabolic load, the angle of side prisms sliding will be different, and, consequently, a side pressure will receive a different numerical value.

The problem of determining the side pressure value is reduced to finding the position of such sliding plane at which a side pressure on a enclosing plane will be the greatest.

According to Prokofiev's method the inclination angle of the slip plane determines the greatest pressure on the enclosing wall and this angle was obtained equal to $\theta=\frac{90^{\circ}+\varphi}{2}$.

In is known that with a uniformly distributed load of prisms, the point of application of a side pressure is the center of gravity of the stress diagram, which is represented in the form of a rectangular trapeze. Bases of this trapeze are following:

- the upper base $-\gamma h_{0} t g^{2}=\frac{90^{0}-\varphi}{2}$;

- the lower base $-\gamma\left(h_{0}+H\right) t g^{2}=\frac{90^{0}-\varphi}{2}$; if a height is equal to $H$.

The center of gravity of this trapeze is at a vertical distance from the lower base which equals $\frac{H}{3} \cdot \frac{3 h_{0}+2 h}{2 h_{0}+H}$, where $h_{0}$ is a height of a uniformly distributed load $h_{0}$ equals the assumed height of the natural equilibrium arch.

A mountain pressure in underground mine workings is manifested in the form of extrusion of rocks in the direction of their outcrop. Under the influence of vertical pressure on the rock massif, this mountain pressure tends to move laterally, it creates a lateral pressure, which is usually called a side expansion.

According to [4], that the side pressure is defined by the following formula

$$
\sigma_{\mathrm{x}}=\frac{\mu}{1-\mu} \gamma H, t / m^{2},
$$

where $\frac{\mu}{1-\mu}=m_{6}$ is a coefficient of side expansion under deformations within elasticity

$-\mu$ is Poisson's coefficient;

$-\gamma H$ is a vertical stress, $t / m^{2}$.

The coefficient of a side expansion for the limiting and stress state is determined by the formula

$$
m_{\sigma}=\frac{\sigma_{\Gamma}}{\sigma_{\mathrm{B}}}
$$

where $\sigma_{\Gamma}$ is a horizontal tension, $t / m^{2} ; \sigma_{\mathrm{B}}$ is a vertical stress, $t / \mathrm{m}^{2}$.

In the paper [5] the boundaries of a deformation of a rock massif for underground development of deposits are determined by the construction of a arch of natural equilibrium above a mine working. The boundaries of a arch of collapse or a arch of natural equilibrium are defined by curved slip lines of three families.

Determination of the boundary of a displacement of a earth massive by curved lines of slip surfaces, depending on the geological conditions and the parameters of a clearing space, is given in [5] for the first time. The main carrier of information for constructing of slip lines is the rock solidity passport.

A envelope curve of limit stresses is usually adopted in the form of known from geometry curves, namely, of parabola, hyperbola or straight line, which does not always reflect the actual form that is obtained from experiments.

In the paper [5] the equation of envelopes of limiting stress circles is derived on the basis of the theory of damped oscillations, and as a result we obtain the following equation.

$$
\tau_{n i}=\sigma_{\text {сж }}\left(0.5 \cos \rho_{\text {сж }}+\left\{1-K \exp \left[-\left(\sigma_{n i / \sigma_{\text {сж }}}\right)\right]\right\} \operatorname{tg} \rho_{\text {сж }}\right),
$$

where $\sigma_{\text {сж }}$ is a limit of rocks strength for uniaxial compression, $t / m^{2} ; \sigma_{\text {сж}^{-}}$Normal stress in the region of compressive stresses, $t / m^{2} ; \quad \rho_{\text {сж }}$ is an angle of internal friction under uniaxial compression, deg.; $K=\exp \left[0.5\left(1-\sin \rho_{\text {сж }}\right)\right]$.

By the obtained equation of the envelope of the limiting stress circles, the angular, strength, linear values and the coefficients of the side extension are determined. Depending on the stressed state of rocks, the coordinates of the curves of the slip lines are determined. 
According with formula (3) and Figure 1 graph-analytical by the method of calculation horizontal $\sigma_{\Gamma}$ and vertical $\sigma_{\mathrm{B}}$; stresses is founded:

$$
\begin{aligned}
& \sigma_{\Gamma}=\sigma_{n i}-\tau_{n i} \operatorname{tg} \varphi_{i}, t / m^{2} ; \\
& \sigma_{\mathrm{B}}=\sigma_{n i}+\tau_{n i} \operatorname{ctg} \varphi_{i}, t / m^{2}
\end{aligned}
$$

and then the coefficient of a side expansion in the region of compressive stresses is equal to

$$
m_{\sigma}=\left(\sigma_{n i}-\tau_{n i} \operatorname{tg} \varphi_{i}\right) /\left(\sigma_{n i}+\tau_{n i} \operatorname{ctg} \varphi_{i}\right) .
$$

In the zone of tensile forces the envelope of $\mathrm{c}$ limiting stress circles is described by the parabola equation:

$$
\tau_{n i}=\left[p\left(\sigma_{n i}+\sigma_{p}\right)\right]^{1 / 2},
$$

where

$$
p=(2-(2 \sqrt{ } n+1)+n) \sigma_{p}
$$

is dimensionless quantity;

$\sigma_{p}$ is a normal stress on uniaxial tension, $t / \mathrm{m}^{2}$;

$$
\begin{gathered}
\sigma_{\Gamma}=\tau_{n i} t g \varphi_{i}-\sigma_{n i}, t / m^{2} ; \\
\sigma_{\mathrm{B}}=\sigma_{n i}+\tau_{n i} \operatorname{ctg} \varphi_{i}, t / m^{2} .
\end{gathered}
$$

Then the coefficient of a side expansion in the region of limited tensile stresses is equal to

$$
m_{\sigma}=\left(\tau_{n i} t g \varphi_{i}-\sigma_{n i}\right) /\left(\sigma_{n i}+\tau_{n i} \operatorname{ctg} \varphi_{i}\right) .
$$

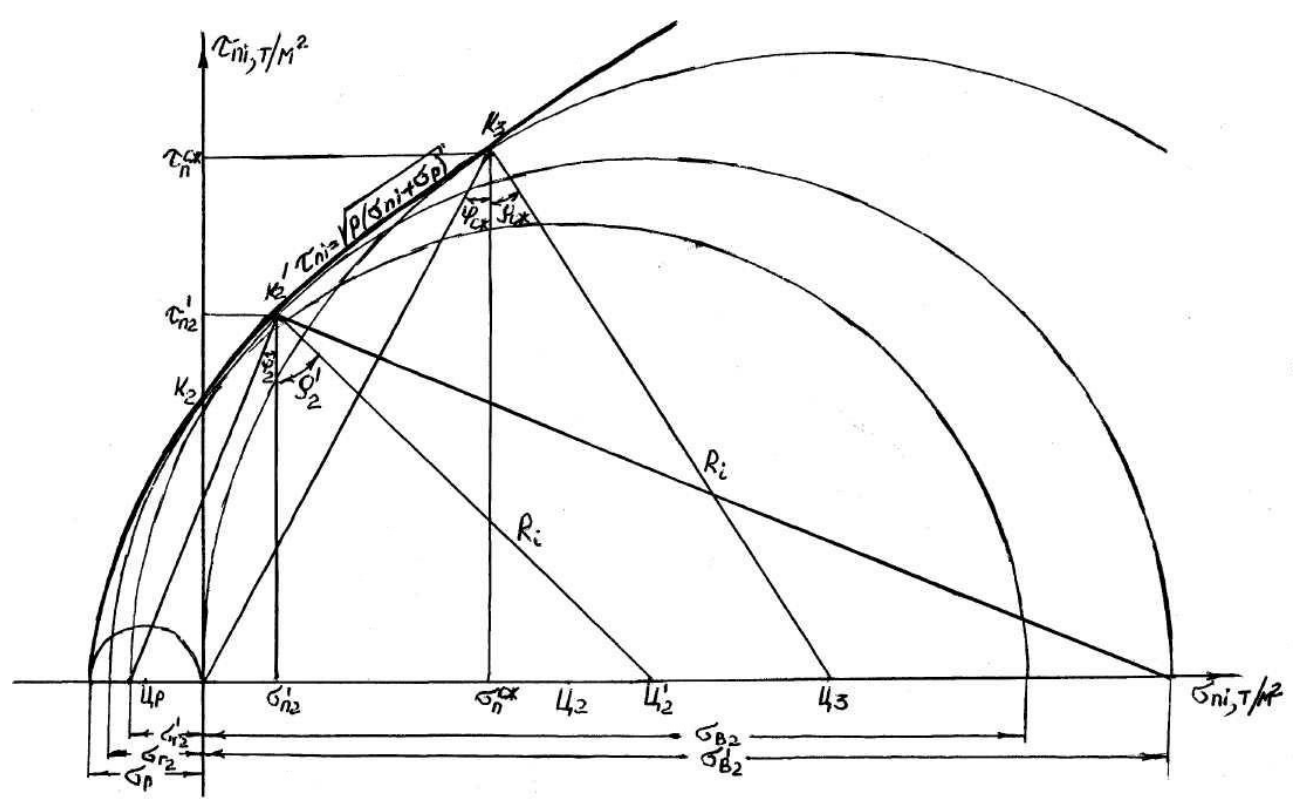

Figure 1. The passport of rock strength. The envelope of the limiting circles Mora

In the last case the angle of an internal friction or the angle between the tangent to the i-th limiting circle and the horizontal line $\rho_{i}$ is equal to:

$$
\begin{gathered}
\rho_{i}=\operatorname{arctg}\left[\frac{p}{2 \sqrt{ }\left[p /\left(\sigma_{n i}+\sigma_{p}\right)\right]}\right] ; \\
n=\sigma_{\text {сж }} / \sigma_{p} .
\end{gathered}
$$


In the zone of an action of tensile stresses, the envelope of Moore's limiting circles is described by the equation of the straight line [6]:

$$
\tau=\sigma_{n i} \operatorname{tg} \rho+C
$$

where $\sigma_{n i}$ is a normal stress on uniaxial tension or compression, $t / m^{2}, \mathrm{C}$ is a clutch.

The envelope of tensile forces is not tangent to the rectilinear envelope, the coefficient of a side expansion $m_{\sigma}$ under uniaxial tension is zero.

From Figure 2 by graphically-analytical way, described above, it is possible to obtain respectively horizontal and vertical stresses:

$$
\sigma_{\Gamma}=\sigma_{n i}+\tau_{n i}^{p} t g \varphi, t / m^{2},
$$

where the tangential stress in the zone of action of tensile stresses is defined by this formula

$$
\tau_{n i}^{p}=C-\sigma_{n i} t g \varphi, t / m^{2} .
$$

The vertical stress is found by the formula

$$
\sigma_{\mathrm{B}}=2 R_{i}-\sigma_{\mathrm{r}}, t / m^{2},
$$

where the radius of the i-th limiting circle is in Figure 2 as follows

$$
R_{i}=\tau_{n i} / \cos \rho .
$$

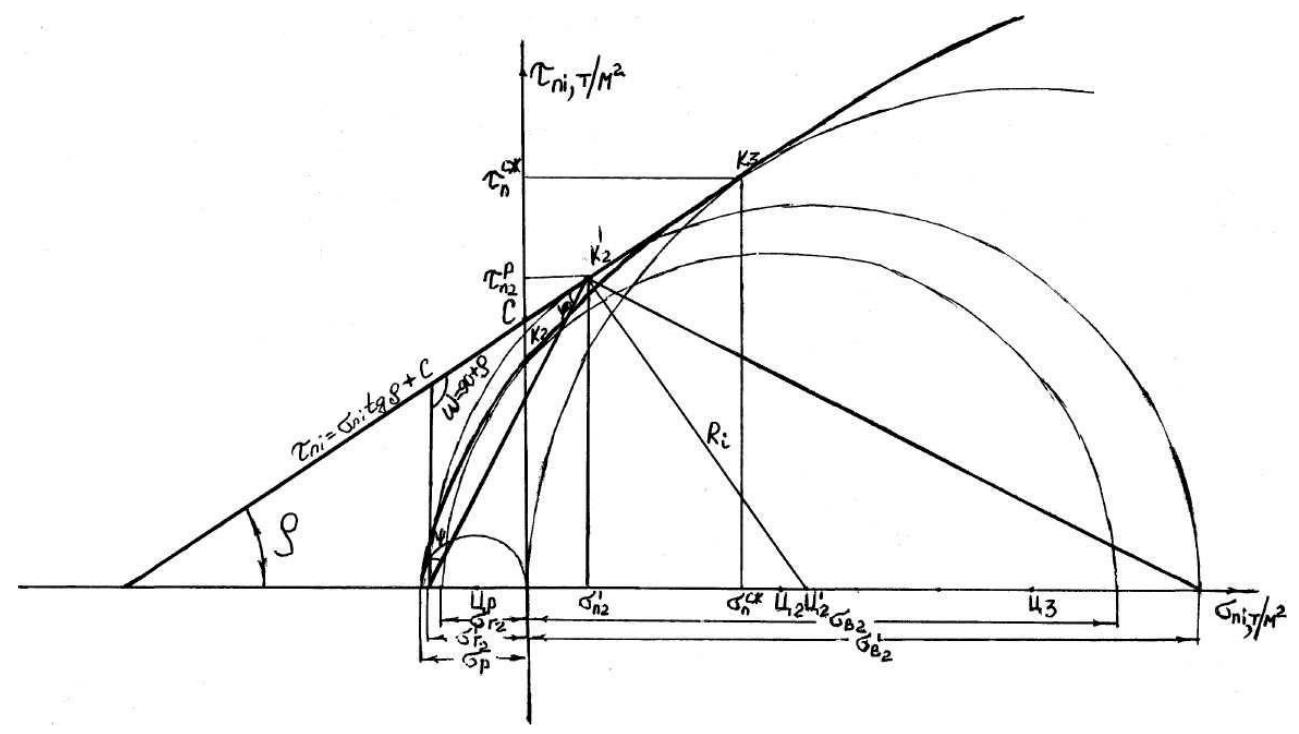

Figure 2. The straight line envelope

Then substituting (18) and (15) into (17) one can obtain a vertical stress in the region of tensile forces

$$
\sigma_{\mathrm{B}}=\left(2 \tau_{n i} / \cos \rho-\left(\sigma_{n i}+\tau_{n i}^{p} t g \varphi\right)\right), t / m^{2} .
$$

Knowing $\sigma_{\Gamma}$ and $\sigma_{\mathrm{B}}$, it is possible to find the formula for the coefficient of a side expansion $m_{6}$ in the zone of limited tensile stresses

$$
m_{\text {б }}=\left(\sigma_{n i}+\tau_{n i}^{p} \operatorname{tg} \varphi\right) /\left(2 \tau_{n i}^{p} / \cos \rho-\left(\sigma_{n i}+\tau_{n i}^{p} \operatorname{tg} \varphi\right)\right) .
$$

Due to the fact that in the extension region the limit circles are described by a rectilinear envelope of the values of the internal friction angles, $\rho$ and sliding surfaces $\varphi$, respectively, will be equal to the values under uniaxial compression. 
Analytical research of rocks properties in conditions of volume stress state were carried out by calculation for passports of the rocks strength as strong (gray sandstones $\sigma_{\text {сж }}=8000 t / \mathrm{m}^{2}$ ) as weak (siltstones $\sigma_{\text {сж }}=185 t / \mathrm{m}^{2}$ ). The envelopes of limited stress circles on the strength passport and the rectilinear envelope were compared for the most accurate determination from the mathematical expressions of $m_{\sigma}$ in figures 1 and 2 in the region of limiting tensile stresses for various geological conditions.

If formulas (11) and (20) are compared, the values of normal and tangential stresses and the angle of the slip surface and internal friction are substituted then it can be obtained that they have the same significance, and, consequently, the side pressure coefficients for rectilinear and curvilinear envelopes in the zone of limiting tensile stresses will be equal.

\title{
References
}

1 Слесарев В.Д. Механика горных пород / В.Д. Слесарев. - М.: Углетехиздат, 1948. - 303 с.

2 Цимбаревич П.М. Механика горных пород / П.М. Цимбаревич // ОНТИ-НКТП-СССР. Гос. науч.техн. гор.-геол.-нефт. изд-во. - М.-Л.-Грозный-Новосибирск, 1934. - 170 с.

3 Протодьяконов М.М. Крепление горных выработок: справочник по каменноугольному делу / М.М. Протодьяконов. Изд. Донугля. - Харьков. - М.: Изд. НТУ; ВСНХ СССР, 1928. - 205 с.

4 Беляев Н.М. Сопротивление материалов / Н.М. Беляев. - М.: Наука, 1976. - 608 с.

5 Сәбденбекұлы Ө. Таужыныстың жылжуының физикасы / Ө. Сәбденбекұлы. - Жезқазған, 1999. 192 б.

6 Ильницкая Е.И. Свойства горных пород и методы их определения / Е.И. Ильницкая, Р.И. Тедер, Е.С. Ватолин, М.Ф. Кунтыш. - М.: Недра, 1969. - 392 с.

\section{М.Ж. Балпанова, Г.А. Есенбаева, Д.К. Таханов \\ Шектік кернеулілік жағдайда бүйір қысым коэффициентін анықтау}

\begin{abstract}
Мақалада шектік кернеулілік күйі мақсатында бүйір қысым коэффициентінің анықтау әдісі қарастырылған. Мықтылық құжаттағы және тік бағытты орам сызықтары созылмалы кернеу шегінде әр түрлі геологиялық жағдайлар үшін, шектік кернеудің орам шеңберінде салыстырылды. Қысылған және созылған кернеу аймағында бүйір қысым коэффициентін анықтау әдісінің графикалық есебі келтірілген және нәтижелерінің салыстырмалы талдауы өткізілген. Орам сызық қисық не тік сызықты болса да, созылым күштері аймағындағы бүйір қысым коэффициентінің тең болатыны дәлелденді.
\end{abstract}

Kiлm сөздер: беріктік паспорты, Пуассон коэффициенті, көлденең қысым, тау кені, Мор шеңберлері, бүйірлік кеңейту, шахтада жұмыс жасау.

\section{М.Ж. Балпанова, Г.А. Есенбаева, Д.К. Таханов}

\section{Расчет коэффициента бокового давления в условиях предельного напряженного состояния}

В статье рассмотрен метод определения коэффициента бокового распора в условиях предельного напряженного состояния. Сопоставлены огибающие кругов предельных напряжений на паспорте прочности и прямолинейная огибающая в области предельных растягивающих напряжений для различных геологических условий. Приведен расчетно-графический метод определения коэффициента бокового распора в областях сжимающих и растягивающих напряжений, проведен сравнительный анализ его результатов. Доказано, что коэффициенты бокового распора для прямолинейной и криволинейной огибающих в зоне предельных растягивающих напряжений равны.

Ключевые слова: паспорт прочности, коэффициент Пуассона, поперечное давление, горная порода, круги Мора, боковое расширение, работа в шахте. 


\section{References}

1 Slesarev, V.D. (1948). Mekhanika gornykh porod [Mechanics of rocks]. Moscow: Ugletekhizdat [in Russian].

2 Tsymbarevich P.M. (1934). Mekhanika gornykh porod [Mechanics of rocks/. Moscow-Leningrad-GroznyNovosibirsk: ONTI-NKTP-SSSR. Gos. nauch.-tekhn. gorno-geologo-neftianoe izdatelstvo - ONTI-NKTPUSSR. State sci. and tech. mining-geological-oil publ. House [in Russian].

3 Protodyakonov M.M. (1928). Kreplenie gornykh vyrabotok: cpravochnik po kamennougolnomu delu [Mounting of mine workings: a handbook of Carboniferous]. Publ. Donugol, Kharkov. Moscow: Izdanie NTU; VSNKh SSSR [in Russian].

4 Belyaev, N.M. (1976). Soprotivlenie materialov [Resistance of materials]. Moscow: Nauka [in Russian].

5 Sabdenbekuly, U. (1999). Tauzhynystyn zhylzhuynyn fizikasy [Rock forced physics]. Jezkazgan [in Kazakh].

6 Ilnitskaya, E.I., Teder, R.I., Vatolin, E.S., Kuntysh, M.F. (1969). Svoistva gornykh porod $i$ metody ikh opredeleniia [Properties of rocks and methods for their determination]. Moscow: Nedra [in Russian]. 